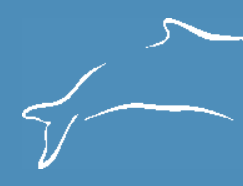

\begin{tabular}{|c|c|}
\hline \multicolumn{2}{|c|}{ Article Info } \\
\hline Manuscript type & Article \\
\hline \multicolumn{2}{|l|}{ Article history } \\
\hline Received & 23 April 2012 \\
\hline Received in revised form & 02 July 2013 \\
\hline Accepted & 06 March 2014 \\
\hline Available online & 26 December 2015 \\
\hline \multicolumn{2}{|c|}{ Keywords: Orinoco, Amazon, fisheries, conflicts } \\
\hline \multicolumn{2}{|c|}{ Responsible Editor: Miriam Marmontel } \\
\hline \multicolumn{2}{|c|}{$\begin{array}{l}\text { Citation: Trujillo, F., Caro, A., Martínez, S. and Rodríguez- } \\
\text { Maldonado, M.V. (2015) Negative interactions between giant } \\
\text { otters (Pteronura brasiliensis) and local fisheries in the Amazon } \\
\text { and Orinoco basins in Colombia. Latin American Journal of } \\
\text { Aquatic Mammals 10(2): 122-130. } \\
\text { http://dx.doi.org/10.5597/lajam00204 }\end{array}$} \\
\hline
\end{tabular}

\title{
Negative interactions between giant otters (Pteronura brasiliensis) and local fisheries in the Amazon and Orinoco basins in Colombia
}

\author{
Fernando Trujillo ${ }^{\dagger, *}$, Andrea $\mathrm{Caro}^{\dagger}$, Sindy Martí- \\ nez $^{\dagger}$ and María Victoria Rodríguez-Maldonado ${ }^{\dagger}$ \\ ${ }^{\dagger}$ Fundación Omacha, Calle 84-21-64, Bogotá, Colombia \\ *Corresponding author, email: fernando@omacha.org
}

\begin{abstract}
The apparent population recovery of giant otters during the last ten years in the Amazon and Orinoco basins in Colombia is creating serious conflicts between local fisheries and this species. This paper presents evidence of conflicts in the Orinoco, Meta and Bita rivers in the Orinoco basin, in the Inírida and Guaviare rivers, and in the Caquetá, Putumayo and Amazon rivers in the Amazon region. In most cases, fishermen are killing giant otters or are asking the government authorities to take action to reduce their numbers. Preliminary evaluations of giant otter diets indicated little competition with local fisheries. However, areas with more intense conflicts corresponded to regions with strong fishing pressure and bad management practices. We conclude that interference with fisheries by giant otters is relatively low but it is necessary to undertake management of the fisheries in the region to avoid perceived conflicts.
\end{abstract}

Resumen. La aparente recuperación poblacional de las nutrias gigantes durante los últimos diez años en el Amazonas y Orinoco colombiano está creando conflictos serios entre algunas pesquerías locales y estas especies. Este artículo presenta evidencia de estos conflictos en los ríos Orinoco, Meta, Bita, Inírida, Guaviare, Caquetá, Putumayo y Amazonas. En la mayoría de los casos los pescadores están matando nutrias en retaliación y solicitan a las autoridades ambientales del gobierno acciones concretas para reducir sus poblaciones. Evaluaciones preliminares de la dieta de las nutrias gigantes muestran poca superposición de items alimentarios con las pesquerías. Un resultado importante es que las áreas de mayor conflicto corresponden a aquellas con mayor presión pesquera y malas prácticas de pesca. Concluimos que la interferencia con pesquerías es relativamente pequeña, pero es necesario implementar medidas de manejo pesquero en las regiones de conflicto. 


\section{Introduction}

Giant otters were severely reduced in density in Colombia and in most of the countries they inhabited during the sixties due to the fur trade (Donadio, 1978; Trujillo et al., 2006). However, during the last fifteen years a recovery of some populations has been reported in the Amazon and Orinoco basins (Botello, 2000; Carrasquilla and Trujillo, 2004; Valderrama et al., 2010), and in neighboring countries, such as Peru and Bolivia (Van Dame et al., 2001; Recharte and Bodmer, 2009). The distributional range of otters has increased and fisheries have moved up streams and along lakes, which generates more interactions and potential conflicts between this species and fishermen (Carrera, 2003; Trujillo et al., 2006; Carrera, 2007; Recharte et al., 2009; Rosas-Ribero et al., 2011). The current distribution of $P$. brasiliensis in the Amazon and Orinoco rivers in Colombia includes black-water streams and white-water (turbid) rivers, confluence areas, lakes and even rocky areas in the middle of the Orinoco River (Carrasquilla, 2002; Trujillo et al., 2006; Botello, 2009; Suárez, 2010). The apparent increase in giant otter populations is creating conflicts with local fishermen because the latter argue that fish stocks are decreasing quickly in areas where the species is present. This kind of negative interaction between fisheries and aquatic predators is increasing throughout the Amazon, not only with giant otters, but also with river dolphins and black caimans (Bonilla et al., 2008; Trujillo et al., 2010). We have reports of at least six areas in Colombia where conflicts with giant otters are occurring and we present an evaluation of the situation and the actions that local authorities are trying to implement with local communities.

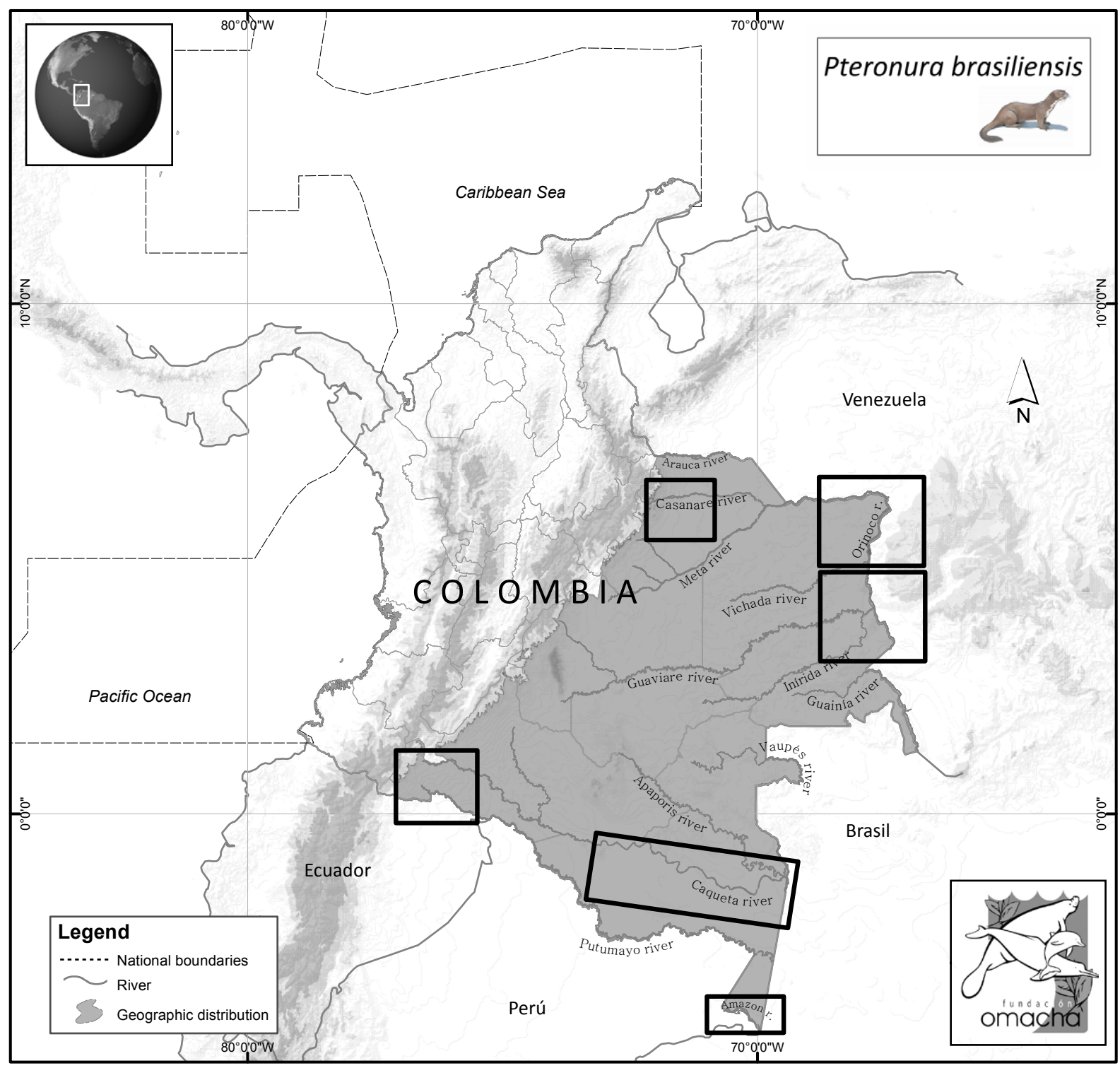

Figure 1. Study area showing the six regions where conflicts between giant otters and fisheries were evaluated 
Table 1. Type of conflicts between giant otters and fisheries in the Amazon and Orinoco basins in Colombia

\begin{tabular}{|c|c|c|c|}
\hline Region & River & Type of conflicts & Description \\
\hline \multirow{3}{*}{ Amazon } & Amazon & None & $\begin{array}{l}\text { Numbers of giant otters are very } \\
\text { low and no interactions with } \\
\text { fisheries have been reported }\end{array}$ \\
\hline & $\begin{array}{l}\text { Caquetá, including Peña Roja } \\
\text { community, and Mirití Parana }\end{array}$ & Biological and operational & $\begin{array}{l}\text { Competition for fish during fishery } \\
\text { operations and interactions with } \\
\text { hooks and nets }\end{array}$ \\
\hline & $\begin{array}{l}\text { Putumayo, the area of } \\
\text { Tarapaca and La Paya }\end{array}$ & Biological and operational & $\begin{array}{l}\text { Negative interactions with } \\
\text { ornamental fisheries (Osteoglossum } \\
\text { bicirrhosum) and commercial } \\
\text { fisheries }\end{array}$ \\
\hline \multirow{3}{*}{ Orinoco } & Meta, Bita and Orinoco rivers & Biological and operational & Conflicts in tributaries and lakes \\
\hline & $\begin{array}{l}\text { Guaviare, Inírida and Atabapo } \\
\text { rivers (Inírida Fluvial Star) }\end{array}$ & Biological and operational & $\begin{array}{l}\text { Conflicts with fisheries, killing of } \\
\text { otters }\end{array}$ \\
\hline & Casanare & Operational & $\begin{array}{l}\text { Negative interactions with } \\
\text { aquiculture }\end{array}$ \\
\hline
\end{tabular}

\section{Material and Methods}

Interactions between giant otters and fisheries have been evaluated in six regions of Colombia: three in the Orinoco Basin and three in the Amazon Basin (Figure 1). In the Orinoco, the areas are located at the confluence of the Meta, Bita and Orinoco rivers in the El Tuparro Biosphere Reserve, the Inírida Fluvial Star that includes the Guaviare, Inírida and Atabapo rivers, and some wetlands and rivers supporting aquaculture in Casanare. In the Amazon, evaluations were made in the Amazon, Putumayo and Caquetá rivers.

This paper used information compiled from various projects undertaken by Omacha Foundation and other organizations, between 2004 and 2011, and that have not been published before. Methods to collect the information were different in each area. Data was collected in the Amazon as part of an evaluation of aquatic species (river dolphins, giant otters, turtles and black caimans) and conflicts with human communities in 2009 and 2010 during the FACUAM project (Actions for the use, management and conservation of threatened aquatic fauna of southern Colombian Amazon). This was a large initiative from the Colombian government and two non-governmental organizations (Omacha and Natura) in three rivers of the Colombian Amazon: Putumayo, Caquetá and Amazon. This project involved 4213 people in workshops about aquatic wildlife conservation initiatives. In-depth interviews were made with 38 fishermen and five workshops were conducted with local communities in order to evaluate their perceptions about giant otters. This information was used to construct social maps and lists of threats to wildlife (Bermúdez-Romero et al., 2010). Additionally, seventy surveys for direct and indirect evidence of otters were carried out along $328.3 \mathrm{~km}$ of the Amazon,
Caquetá and Putumayo rivers (Valderrama et al., 2010).

Surveys in the Orinoco basin were carried out in two areas. Evaluation of habitat use, diet and threats to giant otters have been ongoing in the Tuparro Biosphere Reserve since 1998; fecal samples were collected in order to identify the species and the size of the fish that otters were consuming (Gómez, 1999; Valbuena, 1999; Carrasquilla, 2000; Velasco, 2004; Díaz, 2008; Trujillo et al., 2008). Three separate evaluations were conducted in the Inírida Fluvial Star. The first was undertaken between 2005 and 2006 in response to complaints from local indigenous communities about the increase in the number of giant otters and their negative impacts on fisheries. The second was conducted over six months in 2008 evaluating direct and indirect evidence of giant otters and conflicts with fisheries (Suárez, 2010). The last evaluation was made in 2011 and we consolidated all the information in this area and maps were produced of areas of conflict between giant otters and fisheries (Trujillo et al., 2014).

Anecdotal and opportunistic information were collected in 2009 and 2010 during a mammal survey in the Casanare region (Trujillo et al., 2010).

Available information on fisheries was also obtained from national and regional databases in order to identify changes over the last 10 years in target species and capture volumes in the study areas.

\section{Results}

Evidence of biological and operational interactions between giant otters and fisheries was obtained from interviews with local fishermen in five of the six areas (Table 


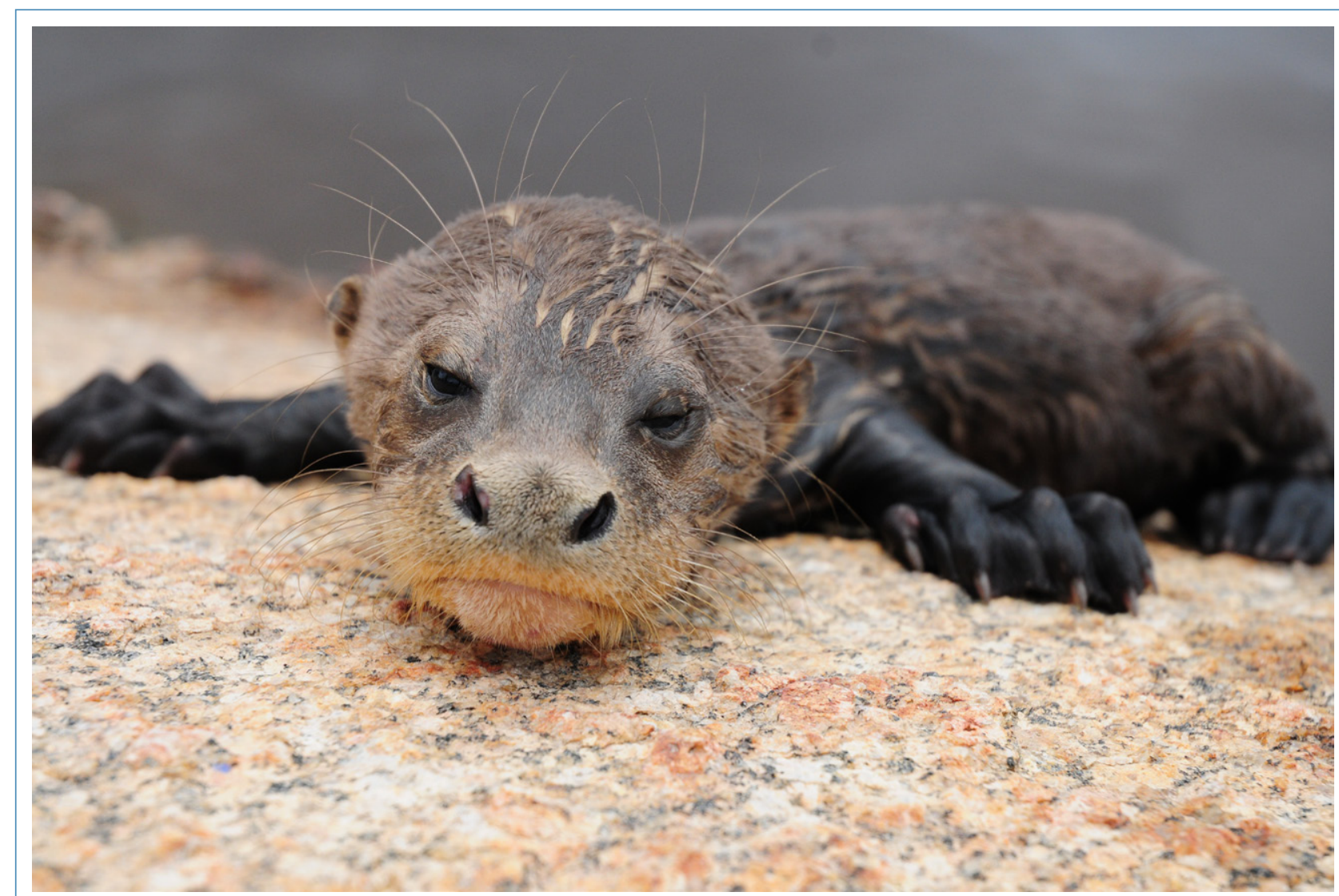

Figure 2. Giant otter pup kept as a pet in an indigenous community in Guainía. The animal died of malnutrition

1). Definitions of these interactions follow Northridge and Hoffman (1999), where biological interactions include competition between giant otters and fisheries for the same prey species, and operational interactions occur when giant otters interact directly with fishing operations, removing fish from nets or scaring the fish.

\section{Amazon Region}

Giant otters are scarce in the Amazon River and are mostly found in upstream tributaries, such as the Loreto Yacu, Atacuari, and Amacayacu and Matamata rivers. The low numbers may be a result of the high hunting pressure during the 1950s and 1960s as the town of Leticia, in the middle of this area, was one of the most important centers of fur gathering (Donadio, 1978). There were no reported interactions between fisheries and otters in this region.

Conflicts were reported in two areas of the Caquetá River, one close to the town of Araracuara in the indigenous community of Peńa Roja, and the other in the Mirití Parana River. In both cases, almost $70 \%$ of fishermen claimed that giant otters scare the fish from lakes and fishing areas. This percentage of the fishermen also argued that otters remove fish from nets and hooks. In retaliation, some of them killed otters, especially adults, and they collected pups as pets for the communities. In most cases (94\%) these pups died due to the lack of proper care and food and sometimes they were just killed (Figure 2). Despite the fact that most fishermen (n $=235$, Figure 3 ) had negative perceptions about giant otters, the traditional beliefs of indigenous communities (Nonuyas, Andoques, Matapíes and Yukunas) hold that this species is important for the equilibrium of the aquatic world. They even consider the origin of giant otters as a mechanism to control diseased fish (Matapi et al., 2008).

On the Putumayo River, evaluations of conflicts were undertaken in two main areas. The first was located on the Caucaya River and La Paya Lake in a tri-border zone between Colombia, Peru and Ecuador. There, conflicts occur between giant otters and commercial and ornamental fisheries. Fishermen argued that otters hunt the silver arowana (Osteoglossum bicirrhosum), and that this makes capture of juveniles for the ornamental fish trade difficult. This conflict has been reported for regions in Colombia and Peru, and has been treated in several projects such as FACUAM, Putumayo three frontiers program and Aquatic threatened fauna in the Colombian Amazon in which 53 meetings were carried out involving fishermen between 2008-2012 (Trujillo et al., 2008; Bermúdez-Romero et al., 2010). In the Guainía and Amazon states in Colombia, fishermen sent inquiry letters asking the Government to reduce the number of otters. This situation encouraged local environment authorities to undertake evaluations of giant otter populations. 


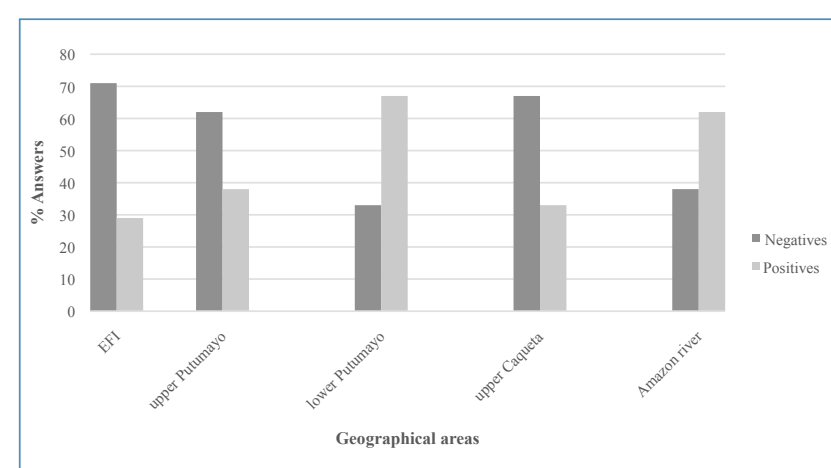

Figure 3. Fishermen negative and positive perceptions towards giant otters in four geographic areas of Colombia. EFI: Fluvial Star of Inírida-Guainía $(\mathrm{n}=48)$, Caquetá ( $\mathrm{n}=$ 23), Putumayo $(n=63)$ and Amazon $(n=101)$

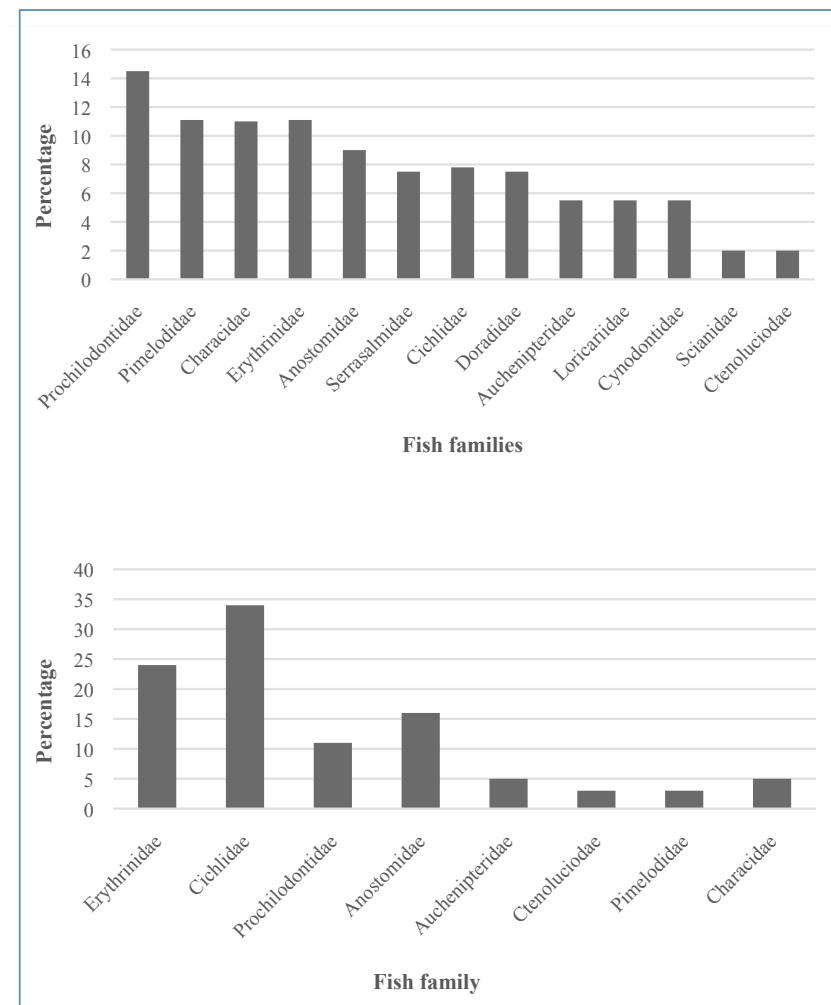

Figure 4. Diet of giant otters in the Inírida Fluvial Star. a) Puerto Carreño, b) Puerto Inírida (based on Carrasquilla and Trujillo, 2004 and Velasco, 2005)

\section{Orinoco Region}

Conflicts were reported in the three areas in the Orinoco Basin. In the Tuparro Biosphere Reserve, fishermen in the Meta and Bita rivers reported an increase in the number of giant otters. The conflicts appear to be biological and operational because otters eat some of the important fish used by the local people for subsistence, especially fish from the families Prochilodontidae (Prochilodus mariae), Erythrinidae (Hoplias sp.), Pimelodidae and Characidae (Figure 4). Six cases of retaliation have been reported for the Juriepe and
Bita rivers, where fishermen usually killed adults and kept the pups as pets. During the last 10 years, five pups have been rehabilitated in the area (Gómez et al., 1999).

In the Casanare region, little research has been conducted specifically on giant otters, but recently surveys to describe the situation of mammals in this area showed conflicts between this species and aquaculture initiatives on the Andean border of the Orinoquia (Trujillo et al., 2011). At least five farmers (41.6\%) expressed their anger towards the presence of giant otters and pay people to shoot and trap these animals in order to prevent attacks on their fish.

In the Inírida Fluvial Star, there appears to be more conflicts because, during the last six years, the indigenous authorities of Puerto Príncipe and Yuri communities have pressured the environmental authorities to reduce the number of giant otters. They argue that there are large groups of otters in most tributaries and lakes and that the fisheries are severely affected by these animals ${ }^{1}$. Very low densities of giant otters were found during field surveys undertaken in 2005 despite the fact that we included some of the fishermen who made complaints and described large groups and densities of otters. Most of the indirect evidence was found upstream far away from human communities. Eighty-three fecal samples were collected showing eight main families of fish with a higher percentage of Cichlidae followed by Erythrinidae and Anastomidae (Figure 4). Most of these species were under $20 \mathrm{~cm}$ of length (estimation based on fish mandibles and linear regressions of mandible length and standard length of measured fish), which represents only a relatively small amount of the target fisheries from local communities. In 2007, 210 linear $\mathrm{km}$ of main rivers and tributaries were sampled to identify areas with giant otters. Thirty-six individuals in eight groups were found in the area (Suárez, 2010). An update of the situation of giant otter in this region was made during two months in 2011. During this time, five indigenous communities (Puinave, Kubeo, Tucano, Kurripaco and Piaroa) and four farms were visited to evaluate the perception of and conflicts with giant otters. During 2007, the groups were reported to remain almost the same with two observed dispersers (individuals that left their natal groups) (Suárez, 2010). The negative perception towards giant otters has been expressed frequently over the last few years and more fishermen are asking for a culling of otters and have even proposed the opening of a pelt trade, a situation that is legally prohibited. Fishermen claim that fish stocks are collapsing due to the high number of giant otters, a situation that is not supported by the counting and the indirect evidence of this species in the area. Also, fishermen claim that otters attack fish traps called cacures and

${ }^{1}$ Garrote, G. (2006) Evaluación preliminar del conflicto nutria gigante (Ptenonura brasiliensis) - pescadores indígenas en la comunidad Puerto Principe (Puerto Inírida-Guainía). Corporación para el Desarrollo Sostenible del Norte y el Oriente Amazónico (CDA)- Fundación Omacha. Informe Técnico, $16 \mathrm{pp}$. 


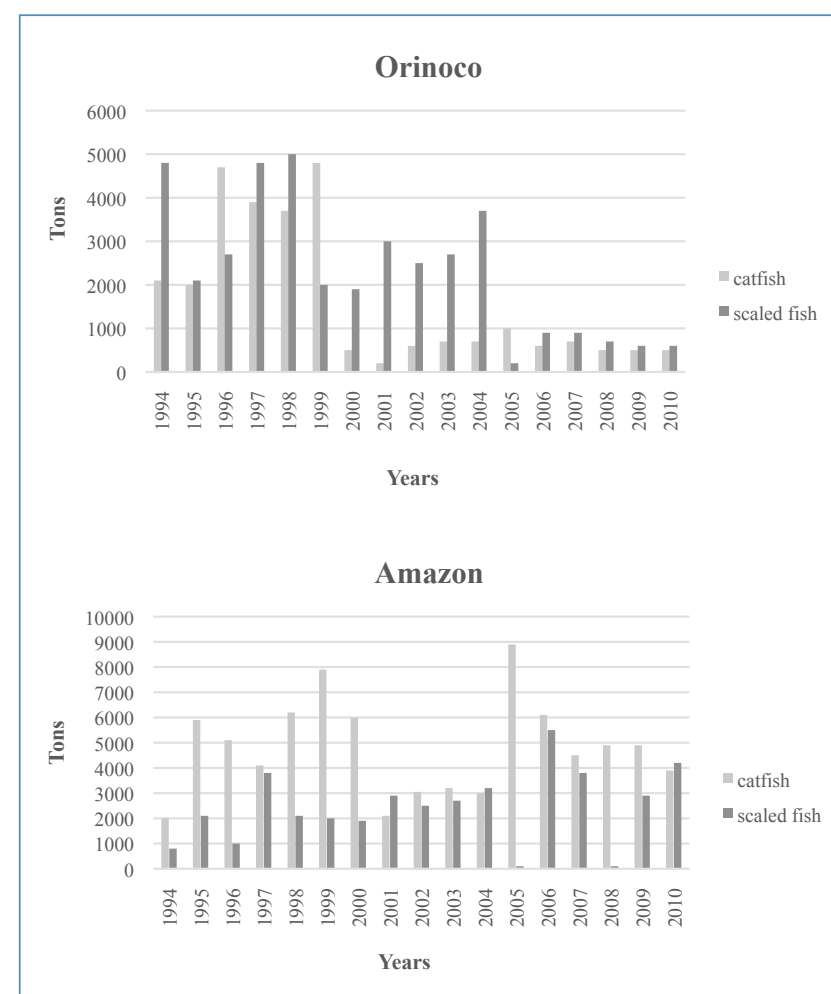

Figure 5. Comparative changes between landed catfish and scaled fish (tons) for the Orinoco (a) and Amazon (b) from 1994 to 2010

nasas in addition to nets. Cacure traps are made with thin sticks, forming a heart-shaped enclosure with a small entrance from which fish that are trapped cannot return. Nasa traps are made from a conical basket made of bark (Ramírez-Gil and Ajiaco-Martínez, 2011).

\section{Fisheries}

In four of the six areas where conflicts between fisheries and giant otters have been reported, fishing is an important economic activity, and the target species are similar (Fabré and Alonso, 1998). Catfish have been the main target species in these areas since the eighties, and the fisheries occurred mainly in large rivers such as the Meta, Orinoco, Guaviare, Putumayo, Caquetá and Amazon (Petrere et al., 2005). The tributaries and lagoons are ecosystems where local people collect fish for their own consumption. However, a significant decrease in capture volumes of catfish has been evident during the last eight years mainly in the Orinoco region (Figure 5a), and the consequence of this was the re-orientation of the fisheries toward the fishes used for local consumption, thus affecting food security for local people. This situation created several conflicts between communities and fish traders that have been complaining to government authorities. In the Amazon the pattern is a little different, with a decrease in capture of catfish from 2002 to 2004 but increasing again from 2005 mainly because of the mota fish trade from Brazil and Peru (Figure 5b).

In the Amazon region, the main areas where conflicts occurred correspond to the Caquetá and Putumayo rivers, where the fisheries were based mainly on catfish. Nevertheless, during recent years, people are trading more fish from the families Characidae, Curimatidae, Prochilodontidae and Anastomidae that traditionally were used for local consumption. Indigenous communities have alerted environmental authorities about this situation and in some cases fishery agreements have been proposed (BermúdezRomero et al., 2010; Valderrama et al., 2010). One of the main problems is that reproductive migrations of fishes are interrupted by large nets blocking confluences and tributaries, which reduce fish recruitment. Additionally, fishermen need to move farther away from riverine towns looking for undisturbed areas (areas that often correspond with giant otter territories) for fish.

In the case of the Meta, Orinoco and Bita rivers the conflict centers around the interest of commercial, ornamental and sport fisheries. All three fisheries generate important income for the region and the country. Sport fisheries claim that the lack of management of commercial fisheries on the border between Colombia and Venezuela encourage bad fishing practices which include the use of large nets in rivers, such as the Bita, where sport fishermen catch pavones (Cichla $\mathrm{sp}$ ) and other fishes. As the capture of catfishes decreased, the pressure has increased on characins and cichlids that are sold in Venezuela. In order to catch these species the fisheries have moved their target areas to small tributaries and lakes, where the probability of interactions with giant otters increases. Unfortunately this situation has not been well documented despite complaints from local communities.

A similar situation occurs in the Inírida Fluvial Star where the fisheries for catfish have been reduced dramatically in their catches and the fisheries have now changed their target species to characids and cichlids that have a viable market in Venezuela. This situation is affecting food security and cultural features of indigenous communities, because most of them catch and sell fishes in the frontier cities and then with the money buy cans of tuna fish for their families (Trujillo et al., 2003).

\section{Discussion}

There have been reports of conflicts between giant otters and fisheries throughout their geographic range (Gómez and Jorgenson, 1999; Carrera, 2007; Recharte et al., 2009; RosasRibeiro et al., 2011). In most cases, local people claim that giant otter numbers have increased and that there are large groups in fishing areas. These conflicts may be summarized as predation of fish (biological interaction), interference with the fishery by scaring the fish in the areas where fishermen are present (interference), and damaging fishing equipment including nets, traps and hooks (operational interaction).

Overfishing is reducing stocks and has increased the area 
that is fished. Our direct observations during the last eight years showed that fishermen are moving from white rivers to areas where this species traditionally resided (black waters) rather than the giant otters expanding their home ranges. For this reason, the frequency of interactions between humans and otters has increased, as Carrera (2007) and Recharte et al. (2009) pointed out for other areas of the Amazon.

Giant otters and other piscivores are unjustly being blamed for the overfishing. This blaming of the giant otters for the reduction of fish stocks is probably overexaggerated by fishermen and may be an excuse to avoid the implementation of fisheries management plans and the endorsement of national fishery regulations and local agreements. This situation has been discussed several times during management workshops in the Colombian Amazon between policy makers, non-governmental organizations and local communities, and corresponds to an increase in fishery products demand in the cities, more people and towns being established along the riverbanks and the collapse of fisheries in several places. In fact, there are areas where the fisheries have collapsed and there is no evidence of the presence of giant otters or even river dolphins (Inia geoffrensis), another species that has been identified by fishermen as a competitor (Trujillo et al., 2014). The situation of the fisheries along the Amazon is starting to be critical and needs to be addressed as a priority by all governments in the region. Additionally, trans-boundary conservation strategies need to be designed, as has been proposed by several authors (Pinedo and Soria, 2008; Barletta et al., 2010).

Another major problem is the change in target species in the fisheries. Large catfish were the main target species for almost two decades, but recently the target species have changed and now include scavenger fish that formerly were rarely eaten in the Amazon. An example is the case of the mota fish (Calophysus macropterus) that now represents more than $40 \%$ of the commercial fisheries in countries like Colombia and is being exported to large cities in different countries where consumers have no idea what they are eating (Trujillo et al., 2011). In most of the evaluated areas where conflicts were reported, commercial fisheries are focusing on fish species that in the past were only used for subsistence consumption. Indigenous people in these areas recognized that in the past there was no conflict between humans and otters because there were enough fish for all. Now the situation is quite different with overfishing, fishermen moving up streams and the use of massive fishery equipment such as driftnets (instead of hooks), traps, harpoons and arrows. Overfishing and the change of species for commercial fisheries are compromising the livelihoods of indigenous people (Ruffino, 2005).

The case of arowana fish is a clear example of how the economic pulses in the Amazon create new pressures on specific resources. The harvest of arowana has been dramatically reduced recently in different geographical areas, and as Recharte et al. (2009) state in the case of Peru, it is more likely that overexploitation for the aquarium trade is the primary cause of the reduction rather than predation by giant otters. For this reason the solution is a regulation of the fisheries rather than predator control.

Another pattern in all these areas is that fishermen are asking the government to take action to reduce the number of otters. Therefore, it is a priority to undertake robust evaluations of giant otter populations in all these areas, involving local people and training them for monitoring of otter populations. Additionally, further actions to evaluate fisheries and promote management plans should be undertaken before it is too late for fisheries and giant otters.

\section{Acknowledgments}

We would like to thank FACUAM's initiative on the head of Corpoamazonía, Sinchi, Omacha and Natura and all the researchers involved on the project. In the same way we are grateful with the CDA and WWF, especially Saulo Usma for their support for the monitoring of giant otters in the Inírida Fluvial Star; Daniel Matapi, Joana Yukuna and Arturo Yukuna for their work in the Caquetá River, and Rosa Elena Ajiaco, Carlos Barreto and CCI for the information on fisheries. Finally, we want to thank the reviewers of this paper for their valuable comments and suggestions.

\section{References}

Barletta, M., Jaureguizar, A.J., Baigun, C., Fontour, N.F, Agostinho, A.A., Almeida-Val, V. M.F., Val, A.L., Torres, R.A., Jimenes-Segura, L.F., Giarrizzo, T., Fabré, N.N., Batista, V.S., Lasso, C., Taphorn, C.D., Costa, M.F., Chaves, P.T., Vieira, J.P. and Corrêa, M.F.M. (2010) Fish and aquatic habitat conservation in South America: a continental overview with emphasis on neotropical systems. Journal of Fish Biology 76: 2118-2176.

http://dx.doi.org/10.1111/j.1095-8649.2010.02684.x

Bermúdez-Romero, A.L., Trujillo, F., Solano, C., Alonso, J.C. and Ceballos-Ruíz, B.L., Eds (2010) Retos Locales y Regionales para la Conservación de la Fauna Acuática del Sur de la Amazonia colombiana. Corpoamazonía, Instituto Sinchi, Fundación Omacha, Fundación Natura, Bogotá, Colombia. 189 pp.

Bonilla, C.A., Agudelo, E., Gomez, C., Alonso, J. and Trujillo, F. (2008) Interacciones entre delfines de río (Inia geoffrensis y Sotalia fluviatilis) y pesquerías de grandes bagres en el río Amazonas. Pages 29-38 in Trujillo, F., Alonso, J.C., Diazgranados, M.C. and Gómez, C. (Eds) (2008) Fauna Acuática Amenazada en la Amazonía colombiana: Análisis y propuestas para su conservación. Fundación Omacha, Corpoamazonía, Instituto Sinchi, Fundación Natura, Bogotá, Colombia. 152 pp. 
Botello, J.C. (2000) Ecología y comportamiento del lobo de rio (Pteronura brasiliensis) en la región del bajo río Apaporis, Amazonia colombiana. Undergraduate Thesis. Universidad del Valle. Cali, Colombia. 64 pp.

Botello, J.C. (2009) El lobo de río Pteronura brasiliensis en el lago del Grillo (Mosiro Itajura): distribución y abundancia en la region del bajo río Apaporis, Amazonía Colombiana. Pages 163-169 in Alarcón-Nieto, G. and Palacios, E. (Eds) Estación Biológica Mosiro Itajura-Caparú: Biodiversidad en el Territorio del Yaigojé-Apaporis. Conservación Internacional Colombia, Bogotá.

Carrasquilla, M.C. (2002) Uso de habitat, comportamiento $y$ dieta de la nutria gigante (Pteronura brasiliensis) en el rio Orinoco. Undergraduate Thesis. Universidad de los Andes. Bogotá, Colombia. 62 pp.

Carrasquilla, M.C. and Trujillo, F. (2004) Uso del hábitat, comportamiento y dieta de la nutria gigante (Pteronura brasiliensis) en el río Orinoco, Vichada. Colombia. Pages 179-202 in Diazgranados, M.C. and Trujillo, F. (Eds) Fauna Acuática en la Orinoquia colombiana. Pontificia Universidad Javeriana, Instituto de Estudios Ambientales para el Desarrollo-IAvH-GTZ. Vol. 6. Serie Investigación. Bogotá, Colombia. 404 pp.

Carrera, P. (2003) Solapamiento de nicho entre el hombre y la nutria gigante (Pteronura brasiliensis, Carnivora: Mustelidae) en la cuenca baja del río Yasuní, Parque Natural Yasuní, Amazonía Ecuatoriana. Undergraduate Thesis. Pontificia Universidad Católica del Ecuador, Facultad de Ciencias Exactas y Naturales. Quito. 185 pp.

Carrera, P. (2007) Giant otters (Pteronura brasiliensis) and humans in the lower Yasuni Basin, Ecuador: spacio-temporal activity patterns and their relevance for conservation. M.Sc. Thesis. Oregon State University. Corvallis, OR, USA. 139 pp.

Díaz, D.L. (2008) Uso de hábitat de nutria gigante Pteronura brasiliensis en segmentos de los ríos Bita y Orinoco en el área de influencia de Puerto Carreño (Colombia). Undergraduate Thesis. Universidad Nacional de Colombia. Bogotá, Colombia. 126 pp.

Donadio, A. (1978) Some comments on otter trade and legislation in Colombia. In Duplaix, N. (Ed.) Otters, Proceedings of IUCN Otter Specialist Group Meeting. IUCN Publication, New Series, 1977, Paramaribo, Suriname.

Fabré, N.N. and Alonso, J.C. (1998) Recursos ícticos no Alto Amazonas: sua importância para as populaçóes ribeirinhas. Boletim do Museu Paraense Emílio Goeldi, série Zoologia 14(1): $19-55$.

Gómez, J. (1999) Ecología alimentaria de la nutria gigante (Pteronura brasiliensis), en el bajo rio Bita, Vichada-Colombia. Undergraduate Thesis. Pontificia Universidad Javeriana. Bogotá, Colombia. 98 pp.
Gómez, J. and Jorgenson. J.P. (1999) An overview of giant otter-fishermen problem in the Orinoco basin in Colombia. IUCN Otter Specialist Group Bulletin 16(2): 90-96.

Gómez, J.R., Jorgenson, J.P. and Valbuena, R. (1999) Report on the rehabilitation and release of two giant river otter (Pteronura brasiliensis) pups in the Bita river (Vichada, Colombia). IUCN Otter Specialist Group Bulletin 16(2): 8689.

Matapi, D., Yucuna, A., Yucuna, J. and Trujillo, F. (2008) Evaluación de las poblaciones de nutrias gigantes en el rio Caquetá. Pages 73-82 in Trujillo, F., Alonso, J.C., Diazgranados, M.C. and Gomez, C. (Eds) Fauna Acuática Amenazada en la Amazonia colombiana: Análisis y propuestas para su conservación. Fundación Omacha, Corpoamazonía, Instituto Sinchi, Fundación Natura, Bogotá, Colombia. 152 pp.

Northridge, S.P. and Hofman, R.J. (1999) Marine mammal interactions with fisheries. Pages 99-119 in Twiss Jr, J.R. and Reeves, R.R. (Eds) Conservation and management of marine mammals. Smithsonian Institution Press, Washington, USA.

Petrere Jr, M., Barthem, R.B., Agudelo, E. and Corrales, B. (2005) Review of the large catfish in the upper Amazon and the stock depletion of piraiba (Brachyplatystoma filamentosum). Reviews in Fish Biology and Fisheries 14: 403-414.

Pinedo, D. and Soria, C., Eds (2008) Elmanejo de las pesquerías en los ríos tropicales de Sudamérica. Centro Internacional de Investigaciones para el Desarrollo, Mayoy Ediciones S.A. Bogotá, Colombia. 327 pp.

Ramírez-Gil, H. and Ajiaco-Martínez, R.E. (2011) Diagnóstico de la pesquería en la Cuenca del Orinoco. Pages 169-198 in Lasso, C.A., de Paula Gutierrez, M.A., MoralesBetancourt, Agudelo, E., Ramírez-Gil, H. and AjiacoMartínez, R.E. (Eds) II Pesquerías continentales de Colombia: cuencas del Magdalena-Cauca, Sinú, Canalete, Atrato, Orinoco, Amazonas y vertiente del Pacifico. Serie Recursos hidrobiológicos y pesqueros continentales de Colombia. Instituto de Investigacion de los Recursos Biológicos Alexander von Humboldt, Bogotá, Colombia.

Recharte, M. and Bodmer, R. (2010) Recovery of the endangered giant otter Pteronura brasiliensis on the YavaríMirín and Yavarín rivers: a success story for CITES. Oryx 44(1): 83-88. http://dx.doi.org/10.1017/S0030605309990196

Recharte, M., Bowler, M. and Bodmer, R. (2009) Potential conflict between fishermen and giant otter (Pteronura brasiliensis) populations by fishermen in response to declining stocks of arowana fish (Osteoglossum bicirhossum) in Northeastern Peru. IUCN Otter Specialist Group Bulletin 25(2): 89-93. 
Rosas-Ribeiro, P.F., Rosas, F.C. and Zuanon, J. (2012) Conflict between fishermen and giant otters Pteronura brasiliensis in Western Brazilian Amazon. Biotropica 44(3): 437-444. http://dx.doi.org/10.1111/j.1744-7429.2011.00828.x

Ruffino, M. (2005) Gestão do Uso dos Recursos Pesqueiros na Amazônia. ProVárzea, Ministério do Meio Ambiente, Instituto Brasileiro do Meio Ambiente e dos Recursos Naturais Renováveis, Manaus, AM, Brazil. 123 pp.

Suárez, J.P. (2010) Evaluación de uso de hábitat de la nutria gigante Pteronura brasiliensis, asociado a problemas de conservación en el río Inírida. Undergraduate Thesis. Universidad Militar Nueva Granada. Bogotá, Colombia. 68 pp.

Trujillo, F., Botello, J.C. and Carrasquilla, M.C. (2006) Perro de agua Pteronura brasiliensis. Pages 133-138 in RodríguezMahecha, J.V., Alberico, M., Trujillo, F. and Jorgenson, J. (Eds) Libro Rojo de los Mamíferos de Colombia. Serie Libros Rojos de Especies Amenazadas de Colombia. Conservación Internacional Colombia and Ministerio de Ambiente Vivienda y Desarrollo Territorial, Bogotá, Colombia.

Trujillo, F., Portocarrero, M. and Gomez, C. (Eds) (2008) Plan de Manejo y Conservación de Especies Amenazadas en la Reserva de Biosfera El Tuparro: Delfines de rio, manaties, nutrias, jaguares y tortugas del género Podocnemis. Proyecto Pijiwi Orinoko (Fundación Omacha-Fundación Horizonte Verde), Forest Conservation Agreement, Bogotá, Colombia. $144 \mathrm{pp}$.

Trujillo, F., Portocarrero, M., Gómez-Salazar, C., Diazgranados, M.C., Castellanos-Mora, L., Ruíz-García, M. and Caballero, S. (2010) Status and conservation of river dolphins Inia geoffrensis and Sotalia fluviatilis in the Amazon and Orinoco basins in Colombia. Pages 29-57 in Trujillo, F., Crespo, E., Van Damme, P. and Usma, J.S. (Eds) The Action Plan for South American River Dolphins 2010-2020. WWF, Fundación Omacha, WCS, WDCS, Solamac. 240 pp.

Trujillo, F., Garavito-Fonseca, J., Gutiérrez, K., RodríguezMaldonado, M.V., Combariza, R., Solano-Perez, L., Pantoja, G. and Ardila, J. P. (2011) Mamíferos del Casanare. Pages 180-205 in Usma, J.S. and Trujillo, F. (Eds) Biodiversidad del Departamento del Casanare: Identificación de Ecosistemas Estratégicos. Gobernación del Casanare-WWF Colombia, Bogotá. 286 pp.
Trujillo, F., Cruz-Antia, D., Caro, A., Martínez, S. and Rodríguez, M.V. (2014) Abundancia de mamíferos acuáticos y conflictos con pesquerías en la Estrella Fluvial de Inírida (Guainía-Colombia). Pages 202-233 in Trujillo, F., Usma, J.S. and Lasso, C.A. (Eds) Biodiversidad de la Estrella Fluvial Inirida. WWF Colombia, CDA, Fundación Omacha, IAvH. Bogotá, Colombia. 328 pp.

Valbuena, R. (1999) Tamaño poblacional y aspectos grupales de la nutria gigante (Pteronura brasiliensis) en el Bajo Río Bita (Vichada, Colombia). Undergraduate Thesis. Universidad Javeriana. Bogotá, Colombia. 65 pp.

Valderrama, E., Hoyos-Rodríguez, M., Correa, L., Caro, X., Bermúdez, A. and Barragán-Romero, J. (2010) Evaluación del conflicto entre la nutria gigante (Pteronura brasiliensis) y las comunidades locales. Pages 89-107 in Bermúdez-Romero, A.L., Trujillo, F., Solano, C., Alonso, J.C. and Ceballos-Ruíz, B.L. (Eds) Retos Locales y Regionales para la Conservación de la Fauna Acuática del Sur de la Amazonia colombiana. Corpoamazonía, Institituto Sinchi, Fundación Omacha, Fundación Natura, Bogotá, Colombia. 189 pp.

Van Damme, P., Wallace, R., Painter, L., Taber, A., Gonzales, R., Fraser, A., Rumiz, D., Tapia, C., Michels, H., Delaunoy, Y., Saravia, J., Vargas, J. and Torres, L. (2001) Distribución y estado de las poblaciones de lontra (Pteronura brasiliensis) en Bolivia. Revista Boliviana de Ecología y Conservación Ambiental 9: 3-13.

Velasco, D.M. (2005) Investigación en Guainia: Estudio preliminar sobre el estado de conservación de la nutria gigante (Pteronura brasiliensis) en la zona de influencia de Inírida (Bajo Rio Inirida) Guainia, Colombia. CDA-Fundación Omacha, Bogotá. 16 pp.

Velasco, D.M. (2004) Valoración biológica y cultural de la nutria gigante (Pteronura brasiliensis) en el area de influencia de Puerto Carreño, Vichada, Colombia (Rios Orinoco, Bita, Caños Juriepe y Negro). Undergraduate Thesis. Universidad Javeriana, Facultad de Estudios Ambientales y Rurales. Bogotá, Colombia. 88 pp. 